\title{
MENINGKATKAN HASIL BELAJAR LEMPAR LEMBING MELALUI MEDIA BAMBU DAN BALON SMP NEGERI 7 BINTAN
}

\author{
Heriwando \\ Guru SMP Negeri 7 Bintan \\ Email: heriwandosmpn7bintan@gmail.com
}

\begin{abstract}
Abstrak
Penelitian ini bertujuan untuk mendapatkan informasi dan mengetahui tentang Meningkatkan Hasil Belajar Dalam Lempar Lembing Melalui Media Bambu dan Balon di Kelas VIII A SMP Negeri 7 Bintan. Jenis penelitian adalah penelitian tindakan kelas dengan subjek penelitian adalah siswa kelas VIII A SMP Negeri 7 Bintan dengan jumlah siswa 23 orang. Penelitian ini terdiri dari dua siklus, dimana siklus I dilaksanakan pada pertemuan 1 dan 2 dan siklus ke II dilaksanakan pada pertemuan 3 dan 4. Masing-masing siklus terdiri dari empat tahap penelitian, yaitu perencanaan, pelaksanaan tindakan, pengamatan dan refleksi. Untuk memperoleh data penelitian digunakan tiga instrumen, yaitu lembar pengamatan, catatan lapangan, dan tes unjuk kerja, yang dianalisis data kualitatif dengan menggunakan persentase. Berdasarkan hasil penelitian menunjukkan bahwa aktivitas belajar siswa kelas VIII A dengan menggunakan Media Lembing Dari Bambu dan Balon mengalami peningkatan dengan persentase ketuntasan $86,96 \%$ yakni 20 orang siswa.
\end{abstract}

\section{Kata Kunci: Hasil Belajar, Media Bambu dan Balon}

\section{PENDAHULUAN}

Menurut UU No 20 tahun 2003, tujuan pendidikan Indonesia adalah : Untuk mengembangkan potensi peserta didik agar menjadi manusia yang beriman bertakwa kepada Tuhan YME, berakhlak mulia, sehat, berilmu, cakap, kreatif, mandiri dan menjadi warga negara yang demokratis serta bertanggung jawab kepada bangsa dan negara.

Era globalisasi menuntut adanya sumber daya manusia yang berkualitas. Upaya mewujudkan sumber daya manusia yang berkualitas harus didukung dengan adanya pendidikan yang baik. Keberhasilan progam pendidikan melalui kegiatan belajar mengajar di sekolah tentu dipengaruhi oleh banyak faktor diantaranya yaitu faktor siswa, guru, biaya, sarana dan prasarana, serta lingkungan.

Sarana prasarana merupakan salah satu bagian yang penting dalam pencapaian tujuan pembelajaran. Kelengkapan sarana prasarana pembelajaran turut mempengaruhi ketercapaian tujuan pembelajaran. Sarana yang lengkap dapat membantu guru untuk mencapai target-target tertentu yang dalam kegiatan pembelajaranya. Sebaliknya sarana yang tidak lengkap akan menjadi kendala bagi guru dalam mencapai tujuan pembelajaranya secara maksimal.

Keberhasilan dalam kegiatan belajar merupakan tujuan yang diharapkan oleh semua guru. Guru harus mampu menciptakan situasi belajar yang efektif. Karena suatu proses pembelajaran yang efektif dan bermakna dapat berlangsung apabila memberikan keberhasilan serta memberikan rasa puas bagi siswa maupun guru. Seorang guru merasa puas jika siswanya dapat mengikuti proses pembelajaran dengan sungguh-sungguh, bersemangat dan penuh kesadaaran yang tinggi. Ini menunjukkan bahwa berhasil atau gagalnya pencapaian tujuan pembelajaran sangat bergantung terhadap proses belajar yang dialami oleh siswa, baik ketika dia berada di lingkungan sekolah maupun saat dia berada di lingkungan rumah atau lingkungan keluarganya sendiri.

Selain tugas ajar dalam penyelenggaraan pendidikan jasmani harus sesuai dengan tingkat perkembangan anak didik yang sedang belajar dan tugas ajar pun harus mampu mengakomodasi perubahan dan perbedaan karakteristik setiap individu serta mendorongnya ke arah perubahan 
yang lebih baik. Pengajaran langsung pada pendidikan jsmani memandang bahwa guru melakukan kontrol yang penuh terhadap apa yang siswa pelajari dan bagaimana prosesnya berlangsung.

Siswa umumnya menyukai pelajaran olahraga, akan tetapi pemikiran kebanyakan siswa pelajaran olahraga adalah kesempatan bermain dan refresing. Apalagi materi pokok yang dipelari adalah olahraga permainan seperti sepakbola, bola volly dan bola basket. Namun apabila materi pokok yang dipelajari adalah olahraga tertutup seperti lari dan lempar lembing motivasi belajar berubah disuruh aktifitas apapun berkaitan lari berat untuk bergerak. Atau melakukan hanya seperlunya dan melepas kewajiban tugas belajar saja. Karena gerakan lempar lembing merupakan gerakan tertutup.

Rendahnya motivasi siswa untuk melakukan aktivitas gerak dan kemampuan dasar lempar lembing berimbas pada hasil belajar lempar lembing. Banyak kesalahan proses gerak teknik dasar lempar lembing yang dilakukan siswa seperti lembing mengenai kepala, lembing jatuh tidak menancap, dan lembing jatu terbalik. Selain motivasi belajar yang kurang sarana prasarana juga kurang memadai untuk mendukung proses belajar lempar lembing, lembing yang ada hanya 1 buah untuk siswa 23 orang dan lapangan untuk praktek harus mencari tempat luar pekarangan sekolah.

Bagaimana hal tersebut dapat disimpulkan setelah melakukan tes awal dari 23 siswa yang melakukan hanya 8 orang yang memenuhi nilai Kriteria Ketuntasan Minimal (KKM) dengan nilai KKM 74. Sadar akan keadaan tersebut, peneliti bermaksud meningkatkan pembelajaran lempar lembing melalui bermain dengan media bambu dan balon.

Berdasarkan permasalahan di atas Adapun tujuan penelitian ini adalah untuk meningkatkan Hasil Belajar Lempar Lembing Melalui Media Bambu dan Balon di Kelas VIII A SMP Negeri 7 Bintan.

Hasil belajar merupakan tujuan akhir dilaksanakannya kegiatan pembelajaran di sekolah. Hasil belajar dapat ditingkatkan melalui usaha sadar yang dilakukan secara sistematis mengarah kepada perubahan yang positif yang kemudian disebut dengan proses belajar. Akhir dari proses belajar adalah perolehan suatu hasil belajar siswa. Hasil belajar siswa di kelas terkumpul dalam himpunan hasil belajar kelas. Semua hasil belajar tersebut merupakan hasil dari suatu interaksi tindak belajar dan tindak mengajar. Dari sisi guru, tindak mengajar di akhiri dengan proses evaluasi hasil belajar, sedangkan dari sisi siswa, hasil belajar merupakan berakhirnya penggal dan puncak proses belajar (Dimyati dan Mudjiono, 2009: 3). Menurut Sudjana (2010: 22), hasil belajar adalah kemampuan yang dimiliki siswa setelah menerima pengalaman belajar. Berdasarkan pendapat para ahli diatas dapat disimpulkan bahwa hasil belajar merupakan adanya perubahan kearah yang positif dari tiga ranah yaitu kognitif, afektif dan psikomotor yang diperoleh siswa setelah dilakukan kegiatan belajar.

Pendidikan Jasmani Olahraga dan Kesehatan (PJOK) pada hakikatnya adalah proses pendidikan yang memanfaatkan aktifitas fisik untuk menghasilkan perubahan holistik dalam kualitas individu, baik dalam hal fisik, mental serta emosional. Pendidikan jasmani Olahraga dan Kesehatan memperlakukan anak sebagai sebuah kesatuan utuh. Pendidikan jasmani Olahraga dan Kesehatan adalah suatu proses pembelajaran melalui aktivitas jasmani yang didesain untuk meningkatkan kebugaran jasmani, mengembangkan keterampilan motorik. Lingkungan belajar diatur secara seksama untuk meningkatkan pertumbuhan dan perkembangan seluruh ranah yaitu, jasmani, psikomotor, kognitif dan afektif. Materi pelajaran jasmani yang meliputi pengalaman teori dan mempraktikkkan keterampilan dasar.

Berdasarkan konsep learning by moving, pendidikan jasmani Olahraga dan Kesehatan memiliki tujuan dan fungsi yang berbeda dengan ilmu pengetahuan lain.

Pendidikan jasmani Olahraga dan Kesehatan memberikan kesempatan kepada siswa untuk terlibat langsung dalam aneka pengalaman belajar melalui aktivitas jasmani, bermain, berolahraga yang dilakukan secara sistematis, terarah, dan terencana. Pembekalan pengalaman belajar itu diarahkan untuk membina sekaligus membentuk gaya hidup sehat dan aktif sepanjang hayat. Dalam proses pembelajaran pendidikan jasmani Olahraga dan Kesehatan guru harus dapat mengajarkan berbagai keterampilan gerak dasar, teknik dan strategi permainan atau olahraga dan pembiasaan hidup sehat. 
Sarana dan prasarana merupakan salah satu bagian yang penting dalam kegiatan pembelajaran. Sarana dan prasarana yang lengkap dapat membantu guru dalam kegiatan proses belajar mengajar. Dengan demikian kelengkapan sarana prasarana pembelajaran akan berpengaruh terhadap tercapainya tujuan pembelajaran.

Kata media merupakan jamak dari kata medium. Medium dapat didefinisikan sebagai perantara atau pengantar terjadinya komunikasi dari pengirim menuju penerima. Menurut Gagne (Rayandra Asyhar, 2012: 7) media adalah berbagai komponen pada lingkungan belajar yang membantu pembelajar untuk belajar. Briggs (Rayandra Asyhar, 2012: 7) mendefinisikan bahwa media sebagai sarana fisik yang digunakan untuk mengirim pesan kepada peserta didik sehingga merangsang mereka untuk belajar. Media pembelajaran menurut Gerlach dan Ely (Rayandra Asyhar, 2012: 8), memiliki cakupan yang sangat luas, yaitu termasuk manusia, materi atau kajian yang membangun suatu kondisi yang membuat peserta didik mampu memperoleh pengetahuan, keterampilan atau sikap. Media pembelajaran mencakup semua sumber yang diperlukan untuk melakukan komunikasi dalam pembelajaran, sehingga bentuknya bias berupa perangkat keras (hardware), seperti komputer, dan perangkat lunak (software) yang digunakan pada perangkat keras itu. Jadi, berdasarkan pengetian menurut ahli di atas, dapat disimpulkan bahwa media pembelajaran adalah segala sesuatu yang dapat menyampaikan sebuah pesan dari penyampai ke penerima pesan secara terencana, sehingga penerima pesan dapat melakukan proses belajar secara efesien dan efektif.

Lempar Lembing merupakan salah satu nomor lempar yang ada dalam olahraga Atletik, Lempar lembing merupakan olahraga yang menggunakan alat yang berbentuk seperti lembing yang kemudian di lempar sejauh mungkin dengan ketentuan - kententuan yang telah di tetapkan. Lempar lembing terdiri dari dua kata yaitu "Lempar" dan "Lembing". Menurut KBBI lempar berarti "buang jauh-jauh" sedangkan Lembing adalah "tombak tohok, tombak kayu yang ujungnya berlapis logam yang runcing untuk berolahraga".

Lembing adalah benda yang terdiri dari 3 bagian yaitu: 1) Mata lembing yang terbuat dari metal. 2) Badan lembing terbuat dari metal, kayu, atau bambu. Badan lembing yang terbuat dari metal di gunakan dalam perlombaan Internasional maupun Nasional. 3) tali pegangan lembing dililitkan di titik pusat lembing. Dalam perlombaan Lempar Lembing Nasional maupun internasional, ada beberapa teknik yang perlu di perhatikan oleh atlet.

Salah satunya adalah teknik memegang lembing, teknik dasar memegang lembing ada 3 cara yaitu 1. Cara Amerika dengan cara pegang bagian belakang lilitan lembing, jari telunjuk melingkar di belakang lilitan lembing dan ibu jari menekan di bagian permukaan lembing lainnya. Sementara itu, jari-jari lainnya turut melingkar di permukaan badan lembing dengan sedikit longgar. 2. Cara Finlandia yaitu : Pada bagian belakang lilitan lembing, yaitu jari tengah dan ibu jari berperan untuk mendorong tali pada lembing.Sementara itu jari telunjuk berada disepanjang batang lembing dan agak serong ke arah yang wajar. Jari-jari lainnya berada pada bagian permukaan lembing yang berada diatasnya. 3. Cara menjepit (Tang) yaitu hanya menjepitkan sebuah lembing di antara dua jari tengah dan jari telunjuk, sedangkan jari-jari lainnya memegang biasa pada permukaan lembing. Kesalahan yang biasa terjadi, ketika memegang lembing yaitu memegang dengan cara yang tidak baik dan nyaman, pegangan kurang kuat, dan tidak diikuti dengan gerak lanjut.

\section{METODE PENELITIAN}

Jenis penelitian yang dilaksanakan sesuai dengan permasalahan yang diteliti adalah Penelitian Tindakan kelas (Classroom Action Research). Penelitian dilaksanakan di SMP Negeri 7. Subjek dalam penelitian ini adalah siswa kelas VIII A SMP Negeri 7 Bintan dengan jumlah siswa 23 orang yang terdiri dari 11 laki-laki dan 12 perempuan. Penelitian dilaksanakan pada semester II tahun ajaran 2019/2020. Prosedur penelitian terdiri dari dua siklus dengan empat tahap penelitian mulai dari perencanaan, pelaksanaan, observasi dan refleksi. Teknik pengumpulan data yang digunakan dalam penelitian ini adalah observasi, tes, wawancara, dokumentasi dan catatan lapangan. Alat pengumpul data dalam penelitian ini meliputi Lembar observasi, Lembar tes, Dokumentasi, Catatan lapangan. Dalam penelitian ini data aktifitas dan hasil belajar 
dianalisis secara deskriptif kuantitatif dengan menggunakan format presentase.

\section{HASIL PENELITIAN DAN PEMBAHASAN}

Paparan Data Pra Siklus. Kegiatan pengambilan data pra siklus dilakukan di kelas VIII A dengan jumlah peserta didik 23 orang. Hasil proses pembelajaran terlihat monoton dan berpusat pada guru, tingkat partisipasi peserta didik dalam belajar rendah, kurang termotivasi dalam belajar, banyak peserta didik yang melakukan percobaan gerak hanya sekedar lepas tugas saja. Untuk lebih jelasnya dapat dilihat pada tabel dibawah ini:

Tabel 1. Rekapitulasi Ketuntasan Belajar Siswa

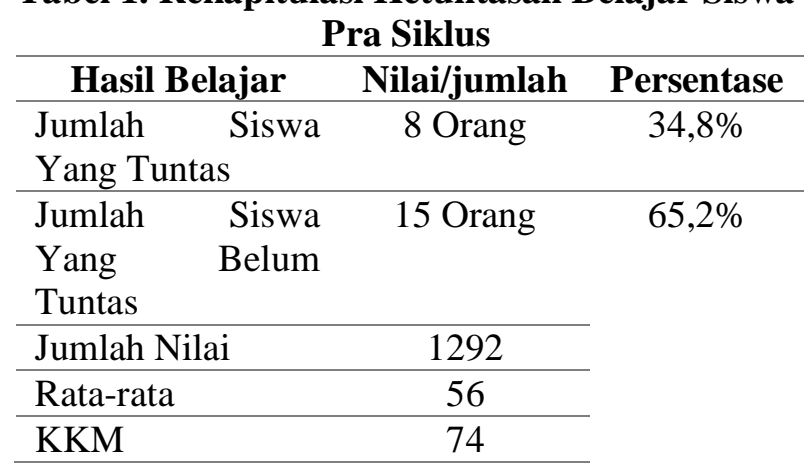

Dari tabel di atas dapat dijelaskan bahwa sebelum menerapkan belajar dengan media bambu dan balon di peroleh rata - rata hasil belajar peserta didik yaitu 56 dengan jumlah siswa yang tuntas sebesar $34,8 \%$ (8 orang siswa) dan selebihnya $65,2 \%$ belum tuntas (15 orang siswa). Dengan demikian, berdasarkan tabel hasil belajar peserta didik diatas serta penjelasannya dapat disimpulkan bahwa masih banyak siswa yang belum tuntas dalam belajar.

Sehingga, masih terdapat 15 dari 23 peserta didik yang belum tuntas belajar atau sebesar $65,2 \%$. Hasil tersebut lebih kecil dari persentase ketuntasan klasikal dalam proses pembelajaran Lempar lembing materi lempar lembing yang dikehendaki sebesar $85 \%$ siswa yang tuntas dalam belajar dengan KKM sebesar 74.

\section{Hasil Penelitian}

\section{Siklus I}

\section{Tahap Perencanaan}

Berdasarkan hasil pengalaman dan proses pengamatan sehari-hari dan refleksi dari proses belajar mengajar, maka dapat diidentifikasi permasalahan-permasalahan yang terjadi pada peserta didik. Berdasarkan permasalahan yang ditemukan kemudian direncanakan apa yang harus dilakukan untuk memperbaiki proses pembelajaran. Berdasarkan permasalahan yang diperoleh, ditetapkan langkah-langkah perencanaan tindakan sebagai berikut: Peneliti dengan observer mengadakan pertemuan untuk menentukan langkah- langkah yang harus dilaksanakan dalam penelitian ini.

Peneliti merencanakan skenario pembelajaran yang sesuai dengan kurikulum dan tingkat kemampuan awal peserta didik berdasarkan hasil kesepakatan bersama dengan observer untuk menyusun sekenario pembelajaran. Adapun sekenario pembelajaran sebagai berikut: Menyiapkan rencana pembelajaran sesuai dengan tujuan yang akan dicapai dalam mata pelajaran PJOK. Menyampaikan tujuan pembelajaran PJOK yang ingin dicapai. Perencanaan kegiatan inti pembelajaran dengan meggunakan format penilaian yang sudah ditentukan. Menyiapkan materi pembelajaran yang diperlukan saat berlangsungnya pembelajaran. Merencanakan model pembelajaran yang akan digunakan saat berlangsungnya penelitian. Menyiapkan format pengamatan proses pembelajaran saat berlangsungnya penelitian. Menyiapkan format penilaian hasil belajar.

\section{Tahap Pelaksanaan}

Pertemuan Pertama Siklus I. Pelaksanaan kegiatan belajar mengajar untuk pertemuan pertama siklus I dilaksanakan pada hari Sabtu tanggal 11 Januari 2020 di Kelas VIII A dengan jumlah siswa 23. Adapun materi pembelajaran pada pertemuan pertama ini adalah Lempar lembing. Adapun proses belajar mengajar mengacu pada rencana pelajaran yang telah dipersiapkan. Pengamatan (observasi) dilaksanakan bersamaan dengan pelaksanaan belajar mengajar. Pertemuan pertama ini diawali dengan kegiatan pendahuluan, kegiatan inti dan kegiatan akhir.

Pendahuluan Guru memberikan salam dan mengajak semua siswa berdo'a menurut agama dan keyakinan masing-masing. Guru mengecek kesiapan diri dengan mengisi lembar kehadiran dan memeriksa kerapihan pakaian. Menginformasikan materi yang akan dibelajarkan yaitu tentang lempar lembing. Guru 
menyampaikan tahapan kegiatan yang meliputi kegiatan mengamati, menanya, mengeksplorasi, mengomunikasikan dan menyimpulkan.

Kegiatan inti dengan melakukan rangkaian tahapan berikut : Siswa diberikan waktu melihat gambar bentuk cara pegang lembing secara berkelompok. Siswa mencobakan dengan menggunakan media bambu. Guru meminta tanggapan dari apa yang mereka lihat dan cobakan. Siswa memberikan tanggapan pegangan yang paling nyaman dan efektif dalam memegang lembing. Siswa diberikan kesempatan melempar jarak pendek dengan pegangan yang benar. Selanjutnya siswa diberikan waktu melihat gambar tahapan teknik dasar melakukan lempar lembing secara berkelompok. Siswa mencobakan lempar lembing dengan media bambu. Siswa melakukan lempar lembing tanpa awalan dengan menggunakan balon yang di gantung pada tali sebagai sasaran. Balon sebagai sasaran diperjauh secara bertahap. Guru meminta tanggapan dari siswa dari apa yang telah dilakukannya. Guru mendemonstrasikan gerakan teknik dasar yang benar secara keseluruhan. Siswa mencobakan menggunakan bambu dan balon sebagai sasaran. Siswa mengenai sasaran diberikan reward. Siswa belum mengenai sasaran diberikan hukuman

Penutup Peserta didik dibariskan kembali dengan memberikan evaluasi pembelajaran membuat kesimpulan. Melaksanakan penilaian dan refleksi dengan mengajukan pertanyaan atau tanggapan peserta didik dari kegiatan yang telah dilaksanakan sebagai bahan masukan untuk perbaikan langkah selanjutnya. Merencanakan kegiatan tindak lanjut dengan memberikan tugas baik cara individu maupun kelompok. Menyampaikan rencana pembelajaran pada pertemuan berikutnya. Senam pendinginan dan menutup pelajaran dengan berdo'a dan salam.

Pertemuan Kedua Siklus I. Pada pertemuan kedua ini dilakukan sebagai upaya untuk memperbaiki proses pembelajaran yang belum maksimal pada pertemuan pertama. Pertemuan kedua dalam siklus I ini dilaksanakan pada hari Sabtu tanggal 18 Januari 2020. Jumlah siswa hadir semuanya 23 orang. Pertemuan kedua ini kembali diawali dengan kegiatan pendahuluan, kegiatan inti dan kegiatan akhir.

Pendahuluan Guru memberikan salam dan mengajak semua siswa berdo'a menurut agama dan keyakinan masing-masing. Guru mengecek kesiapan diri dengan mengisi lembar kehadiran dan memeriksa kerapihan pakaian. Menginformasikan materi yang akan dibelajarkan yaitu tentang lempar lembing. Guru menyampaikan tahapan kegiatan yang meliputi kegiatan mengamati, menanya, mengeksplorasi, mengomunikasikan dan menyimpulkan.

Kegiatan inti dengan melakukan rangkaian tahapan berikut: Siswa dibagi perkelompok. Siswa melakukan permainan menombak menggunakan media bambu ke tanah sambil berjalan, dilakukan dengan 8 kali putaran. Siswa melakukan lempar lembing tanpa awalan dengan menggunakan balon yang di gantung pada tali sebagai sasaran. Siswa melakukan lempar lembing menggunakan langkah awalan dengan menggunakan balon yang di gantung pada tali sebagai sasaran. Bambu yang dilempar harus melewati balon yang direntang dengan tali. Balon sebagai sasaran diperjauh secara bertahap. Guru meminta tanggapan dari siswa dari apa yang telah dilakukannya. Guru mendemonstrasikan gerakan teknik dasar yang benar secara keseluruhan. Siswa mencobakan menggunakan bambu dan balon sebagai sasaran. Siswa melakukan lempar lembing dengan lembing dan lapangan yang sebenarnya. Setiap siswa mencobakan 5 kali secara bergantian

Penutup Peserta didik dibariskan kembali dengan memberikan evaluasi pembelajaran membuat kesimpulan. Melaksanakan penilaian dan refleksi dengan mengajukan pertanyaan atau tanggapan peserta didik dari kegiatan yang telah dilaksanakan sebagai bahan masukan untuk perbaikan langkah selanjutnya. Merencanakan kegiatan tindak lanjut dengan memberikan tugas baik cara individu maupun kelompok. Menyampaikan rencana pembelajaran pada pertemuan berikutnya. Senam pendinginan dan menutup pelajaran dengan berdo'a dan salam.

Observasi. Sesuai dengan tujuan peneliti yaitu Meningkatkan Hasil Belajar Lempar Lembing Melalui Media Bambu dan Balon di Kelas VIII A SMP Negeri 7 Bintan. Hasil belajar diperoleh dari lembar kerja siswa yang dilakukan pada setiap akhir siklus. Data yang diperoleh berupa angka mengenai hasil belajar yang diperoleh masing-masing siswa pada setiap siklus. Untuk lebih jelasnya hasil belajar siswa dapat dilihat pada tabel dibawah ini: 
Tabel 2. Rekapitulasi Ketuntasan Belajar Siswa Siklus I

\begin{tabular}{|c|c|c|}
\hline Hasil Belajar & Nilai/jumlah & Persentase \\
\hline $\begin{array}{c}\text { Jumlah Siswa } \\
\text { Yang Tuntas }\end{array}$ & 16 Orang & $69,57 \%$ \\
\hline $\begin{array}{c}\text { Jumlah Siswa } \\
\text { Yang Belum } \\
\text { Tuntas }\end{array}$ & 7 Orang & $30,43 \%$ \\
\hline Jumlah Nilai & 1767 & \\
\hline Rata-rata & 76,81 & \\
\hline KKM & 74 & \\
\hline
\end{tabular}

Dari tabel di atas dapat dijelaskan bahwa setelah menerapkan media bambu dan balon simulasi pada siklus I ini di peroleh rata - rata hasil belajar peserta didik yaitu 76,81 dengan jumlah siswa yang tuntas sebesar $69,57 \%$ (16 orang siswa) dan selebihnya $30,43 \%$ belum tuntas (7 orang siswa).

Dengan demikian, berdasarkan tabel hasil belajar peserta didik diatas serta penjelasannya dapat disimpulkan bahwa masih banyak siswa yang belum tuntas dalam belajar. Sehingga, masih terdapat 7 dari 23 peserta didik yang belum tuntas belajar atau sebesar 30,43\%. Hasil tersebut lebih kecil dari presentase ketuntasan klasikal dalam proses pembelajaran PJOK yang dikehendaki sebesar $85 \%$ siswa yang aktif dalam belajar dengan KKM sebesar 74.

Refleksi. Dalam tahap refleksi ini peneliti dibantu oleh observer menyampaikan temuan yang dilihat selama proses pembelajaran. Pertemuan ini dilakukan di ruang mejelis guru SMP Negeri 7 Bintan. Hasil diskusi yang dilakukan dengan observer bahwa adapun kekurangan yang ditemukan selam pembelajaran adalah media gambar yang berikan kurang menarik bagi siswa karena media gambar yang digunakan gambar ada dibuku saja dan perpindahan setiap tahapan belajar terlalu cepat, sehingga pengulangan untuk melakukan lempar lembing sedikit untuk mendapatkan pengalaman belajar. Serta guru tidak menyampaikan kesalahan-kesalahan yang sering terjadi saat melakukan lempar lembing. Selain itu jarak target lemparan tidak jelas ukurannya sehingga siswa masih melakukan lemparan tidak sungguh sungguh.

Seharusnya guru harus menyiapkan gambar yang menarik atau berwarna dengan ukuran yang lebih besar atau bisa juga dengan memutarkan video. Dan juga perpindahan setiap tahapan pelajaran perlu juga diperhatikan, supaya pengulangan untuk melakukan lemparan lebih banyak. Menjelaskan terlebih dahulu kepada siswa mengenai kesalahan-kesalahan yang sering terjadi saat melakukan lempar lembing, dan bagaimana cara mengatasinya. Dari masalahan diatas perlu dilakukan siklus selanjutnya, yaitu siklus ke II.

\section{Siklus II \\ Tahap Perencanaan}

Berdasarkan permasalahan yang diperoleh, ditetapkan langkah-langkah perencanaan tindakan sebagai berikut: Peneliti dengan observer mengadakan pertemuan untuk menentukan langkah- langkah yang harus dilaksanakan dalam penelitian ini. Peneliti merencanakan sekenario pembelajaran yang sesuai dengan kurikulum dan tingkat kemampuan awal peserta didik berdasarkan hasil kesepakatan bersama dengan observer untuk menyusun sekenario pembelajaran. Adapun sekenario pembelajaran sebagai berikut: Menyiapkan rencana pembelajaran sesuai dengan tujuan yang akan dicapai dalam mata pelajaran PJOK. Menyampaikan tujuan pembelajaran PJOK yang ingin dicapai. Perencanaan kegiatan inti pembelajaran dengan meggguanakan format penilaian yang sudah ditentukan. Menyiapkan materi pembelajaran yang diperlukan saat berlangsungnya pembelajaran. Merencanakan model pembelajaran yang akan digunakan saat berlangsungnya penelitian. Menyiapkan format pengamatan proses pembelajaran saat berlangsungnya penelitian. Menyiapkan format penilaian hasil belajar.

\section{Tahap Pelaksanaan}

Pertemuan Pertama Siklus II. Pelaksanaan kegiatan belajar mengajar untuk pertemuan pertama siklus II dilaksanakan pada hari Kamis tanggal 23 Januari 2020 di Kelas VIII A dengan jumlah siswa 23 orang. Pada pertemuan ini adapun materinya adalah lempar lembing. Adapun proses belajar mengajar mengacu pada rencana pelajaran dengan memperhatikan revisi pada siklus I, sehingga kesalahan atau kekurangan pada siklus I tidak terulang lagi pada siklus II. Pengamatan (observasi) dilaksanakan bersamaan dengan pelaksanaan belajar mengaja yang terdiri dari kegiatan pendahuluan, kegiatan inti dan kegiatan penutup. 
Pendahuluan Guru memberikan salam dan mengajak semua siswa berdo'a menurut agama dan keyakinan masing-masing. Guru mengecek kesiapan diri dengan mengisi lembar kehadiran dan memeriksa kerapihan pakaian. Menginformasikan materi yang akan dibelajarkan yaitu tentang lempar lembing. Guru menyampaikan tahapan kegiatan yang meliputi kegiatan mengamati, menanya, mengeksplorasi, mengomunikasikan dan menyimpulkan.

Kegiatan inti dengan melakukan rangkaian tahapan berikut: Siswa dibagi 2 kelompok laki dan perempuan. Siswa diberikan kesempatan untuk menonton video tentang lempar lembing dengan durasi 7-8 menit. Siswa memberikan tanggapan tentang yang video Guru meminta komentar dari siswa yang lain. Guru memberikan penjelasan, serta manyampaikan kesalaha-kesalahan yang sering terjadi dalam lempar lembing. Guru mendemonstrasikan rangkaian gerakan lempar lembing. Siswa melakukan permainan menombak menggunakan media bambu ke tanah sambil berjalan, dilakukan dengan 8 kali putaran. Siswa melakukan lempar lembing tanpa awalan dengan menggunakan balon yang di gantung pada tali sebagai sasaran. Dengan penekanan dalam tahap ini adalah jalannya bambu parabola dan memberikan bekas pada tanah. Siswa melakukan lempar lembing menggunakan langkah awalan dengan menggunakan balon yang di gantung pada tali sebagai sasaran. Bambu yang dilempar harus melewati balon yang direntang dengan tali. Balon sebagai sasaran diperjauh secara bertahap. Guru meminta tanggapan dari siswa dari apa yang telah dilakukannya. Guru mendemonstrasikan gerakan teknik dasar yang benar secara keseluruhan. Siswa mencobakan menggunakan bambu dan balon sebagai sasaran. Siswa melakukan lempar lembing dengan lembing dan lapangan yang sebenarnya. Setiap siswa mencobakan 10 kali secara bergantian.

Penutup Peserta didik dibariskan kembali dengan memberikan evaluasi pembelajaran membuat kesimpulan. Melaksanakan penilaian dan refleksi dengan mengajukan pertanyaan atau tanggapan peserta didik dari kegiatan yang telah dilaksanakan sebagai bahan masukan untuk perbaikan langkah selanjutnya. Merencanakan kegiatan tindak lanjut dengan memberikan tugas baik cara individu maupun kelompok. Menyampaikan rencana pembelajaran pada per- temuan berikutnya. Senam pendinginan dan menutup pelajaran dengan berdo'a dan salam.

Pertemuan Kedua Siklus II. Pertemuan kedua ini merupakan upaya untuk lebih memaksimalkan peningkatan proses pembelajaran agar hasil belajar siswa lebih meningkat dari KKM yang ditentukan. Pertemuan kedua dilaksanakan pada hari Sabtu tanggal 1 Februari 2020 dengan jumlah siswa 23 orang. Adapun materi pembelajaran pada pertemuan kedua ini mengacu pada tema menuju masyarakat sehat. Pertemuan kedua diawali dengan kegiatan pendahuluan, kegiatan inti dan kegiatan akhir.

Pendahuluan Guru memberikan salam dan mengajak semua siswa berdo'a menurut agama dan keyakinan masing-masing. Guru mengecek kesiapan diri dengan mengisi lembar kehadiran dan memeriksa kerapihan pakaian. Menginformasikan materi yang akan dibelajarkan yaitu tentang lempar lembing. Guru menyampaikan tahapan kegiatan yang meliputi kegiatan mengamati, menanya, mengeksplorasi, mengomunikasikan dan menyimpulkan.

Kegiatan inti melakukan rangkaian tahapan berikut: Siswa dibagi 2 kelompok laki dan perempuan. Siswa memberikan tanggapan tentang yang video. Guru meminta komentar dari siswa yang lain. Guru memberikan penjelasan, serta manyampaikan kesalaha-kesalahan yang sering terjadi dalam lempar lembing. Guru mendemonstrasikan rangkaian gerakan lempar lembing. Siswa melakukan permainan menombak menggunakan media bambu ke tanah sambil berjalan, dilakukan dengan 8 kali putaran. Siswa melakukan lempar lembing tanpa awalan dengan menggunakan balon yang di gantung pada tali sebagai sasaran. Dengan penekanan dalam tahap ini adalah jalannya bambu parabola dan memberikan bekas pada tanah. Siswa melakukan lempar lembing menggunakan langkah awalan dengan menggunakan balon yang di gantung pada tali sebagai sasaran. Bambu yang dilempar harus melewati balon yang direntang dengan tali. Balon sebagai sasaran diperjauh secara bertahap. Guru meminta tanggapan dari siswa dari apa yang telah dilakukannya. Guru mendemonstrasikan gerakan teknik dasar yang benar secara keseluruhan. Siswa mencobakan menggunakan bambu dan balon sebagai sasaran. Siswa melakukan lempar lembing dengan lembing dan lapangan yang sebenarnya. 
Setiap siswa mencobakan 10 kali secara bergantian.

Penutup Peserta didik dibariskan kembali dengan memberikan evaluasi pembelajaran membuat kesimpulan. Melaksanakan penilaian dan refleksi dengan mengajukan pertanyaan atau tanggapan peserta didik dari kegiatan yang telah dilaksanakan sebagai bahan masukan untuk perbaikan langkah selanjutnya. Merencanakan kegiatan tindak lanjut dengan memberikan tugas baik cara individu maupun kelompok. Menyampaikan rencana pembelajaran pada pertemuan berikutnya. Senam pendinginan dan menutup pelajaran dengan berdo'a dan salam.

Observasi . Pada akhir proses belajar mengajar siswa diberi tes praktek dengan tujuan untuk mengetahui tingkat keberhasilan siswa selama proses belajar mengajar yang telah dilakukan. Hasil belajar diperoleh dari hasil tes unjuk kerja siswa yang dilakukan pada setiap akhir siklus. Data yang diperoleh berupa angka mengenai hasil yang diperoleh masing-masing siswa. Untuk lebih jelasnya dapat dilihat hasil belajar siswa pada siklus II sebagai dapat dilihat pada tabel berikut

Tabel 3. Rekapitulasi Ketuntasan Belajar Siswa Siklus II

\begin{tabular}{|c|c|c|}
\hline Hasil Belajar & Nilai/jumlah & Persentase \\
\hline $\begin{array}{l}\text { Jumlah Siswa } \\
\text { Yang Tuntas }\end{array}$ & 20 Orang & $86,96 \%$ \\
\hline $\begin{array}{ll}\text { Jumlah } & \text { Siswa } \\
\text { Yang } & \text { Belum } \\
\text { Tuntas } & \\
\end{array}$ & 3 Orang & $13,04 \%$ \\
\hline Jumlah Nilai & 2025 & \\
\hline Rata-rata & 88,04 & \\
\hline KKM & 74 & \\
\hline
\end{tabular}

Dari tabel di atas dapat dijelaskan bahwa pada siklus II ini dengan menggunakan media bambu dan balon di peroleh rata - rata hasil belajar peserta didik yaitu 88,04 dengan jumlah siswa yang tuntas sebesar $86,96 \%$ (20 orang siswa). Dengan demikian, berdasarkan tabel hasil belajar peserta didik diatas serta penjelasannya dapat disimpulkan bahwa dengan menggunakan media bambu dan balon dapat meningkatkan hasil belajar siswa pada materi pelajaran lempar lembing, karena sudah hampir semua siswa mencapai KKM. Hasil tersebut sudah baik dan memuaskan dibandingkan siklus I, sehingga target ketuntasan $85 \%$ sudah tercapai, oleh sebab itu maka siklus ini diberhentikan dan tidak perlu dilanjutkan kesiklus berikutnya

Refleksi. Berdasarkan hasil pengamatan peneliti dengan observer melakukan diskusi mengenai proses pembelajaran yang dilakukan diruang majelis guru. Adapun hasil diskusi yang dilakukan dengan observer dapat didiskripsikan bahwa pelaksanaan pembelajaran PJOK dengan menggunakan media bambu pada siklus II dapat meningkatkan hasil belajar siswa materi pelajaran lempar lembing. Sedangkan masalah-masalah yang ditemukan pada siklus I sudah teratasi, baik itu dari guru maupun siswa itu sendiri, oleh sebab itu karena target dan ketuntasan sudah tercapai dan pendekatan yang diterapkan sudah berhasil dilaksanakan maka siklus ini dihentikan dan tidak perlu lagi dilanjutkan ke siklus berikutnya.

\section{Pembahasan Penelitian}

Berdasarkan hasil belajar siswa pada siklus I dan siklus II yang telah dilakukan oleh peneliti, maka terjadi perubahan yang dilihat selama penelitian pada hasil belajar siswa melalui hasil penilitian ini menunjukkan bahwa penggunaan media bambu dan balon memiliki dampak positif dalam meningkatkan hasil belajar siswa dalam materi lempar lembing. Hal ini dapat dilihat dari semakin mantapnya kemampuan siswa terhadap materi yang disampaikan guru (hasil belajar siswa meningkat mulai dari pra siklus, siklus I, dan II secara klasikal.

Sebelum menggunakan media bambu dan balon di peroleh rata-rata hasil belajar peserta didik yaitu 56,16 dengan jumlah siswa yang tuntas sebesar $34,78 \%$ (8 orang siswa) dan selebihnya $65,22 \%$ belum tuntas (15 orang siswa). Dengan demikian, berdasarkan tabel hasil belajar peserta didik diatas serta penjelasannya dapat disimpulkan bahwa masih banyak siswa yang belum tuntas dalam belajar. Sehingga, masih terdapat 15 dari 23 siswa yang belum tuntas belajar atau sebesar $65,22 \%$. Hasil tersebut lebih kecil dari persentase ketuntasan klasikal dalam proses pembelajaran PJOK yang dikehendaki sebesar $85 \%$ siswa yang tuntas dalam belajar dengan KKM sebesar 74 .

Setelah menggunakan media bambu dan balon pada siklus I ini di peroleh rata-rata hasil belajar peserta didik yaitu 76,81 dengan jumlah siswa yang tuntas sebesar 69,57\% (16 siswa) dan selebihnya $30,43 \%$ belum tuntas ( 7 siswa). Hasil tersebut dapat disimpulkan bahwa persentase 
siswa yang tuntas bertambah dari $34,78 \%$ menjadi $69,57 \%$ namun persentase tersebut masih kecil dari persentase ketuntasan klasikal yang dikehendaki sebesar 85\% siswa yang tuntas dengan KKM sebesar 74.

Siklus II ini dengan menggunakan media bambu dan balon dengan perlakuan memutarkan video pada tahap awal dalam inti pembelajaran di peroleh rata-rata hasil belajar peserta didik yaitu 88,04 dengan jumlah siswa yang tuntas sebesar $86,96 \%$ (20 orang siswa). Dengan demikian, berdasarkan tabel hasil belajar peserta didik diatas serta penjelasannya dapat disimpulkan bahwa dengan menggunakan media bambu dan balon dapat meningkatkan hasil belajar siswa, karena sudah hampir semua siswa mencapai KKM.

\section{SIMPULAN DAN SARAN \\ Simpulan}

Sesuai dengan rumusan masalah dan tujuan penelitian yang telah dikemukakan tentang penggunaan modifikasi lembing dari bambu pada materi lempar lembing. Berdasarkan hasil penelitian dalam dua siklus kegiatan disimpulkan terjadi peningkatan hasil belajar siswa pada materi lempar lembing dengan menggunakan media modifikasi lembing dari bambu dan balon pada siswa kelas VIII A SMP Negeri Bintan. Upaya tersebut dapat dibuktikan dengan tindakan yang dilakukan.

\section{Saran}

Dari hasil penelitian yang diperoleh dari uraian sebelumnya agar proses belajar pembelajaran PJOK materi lempar lembing lebih efektif dan memberikan hasil yang optimal bagi peserta didik, maka disampaikan saran sebagai berikut: (1) Ada baiknya media bambu diwarnai menggunakan cat agar menarik bagi siswa, dan balon sebagai sasaran target bisa divariasikan dengan benda lain; (2) Dalam rangka meningkatkan prestasi belajar peserta didik, guru hendaknya lebih sering melatih peserta didik dengan berbagai metode pengajaran, walau dalam taraf yang sederhana, dimana peserta didik nantinya dapat menemukan pengetahuan baru; (3) Perlu adanya penelitian yang lebih lanjut, karena hasil penelitian ini hanya dilakukan di SMPN 7 Bintan VIII.B saja; (4) Untuk penelitian yang serupa hendaknya dilakukan perbaikan-perbaikan agar diperoleh hasil yang lebih baik untuk penelitian selanjutnya

\section{DAFTAR PUSTAKA}

Dimyati dan Drs. Mudjiono.2009. Belajar dan Pembelajaran. Jakarta : Rineka Cipta

Rayandra Asyhar. 2012. Kreatif Mengembangkan Media Pembelajaran. Jakarta: Referensi Jakarta

Salinan Undang-Undang Republik Indonesia No 20 Tahun 2003 Tentang Sistem Pendidikan Nasional

Sudjana, Nana. 2002. Penilaian Hasil Proses Belajar Mengajar. Bandung : Remaja Rosdakarya 